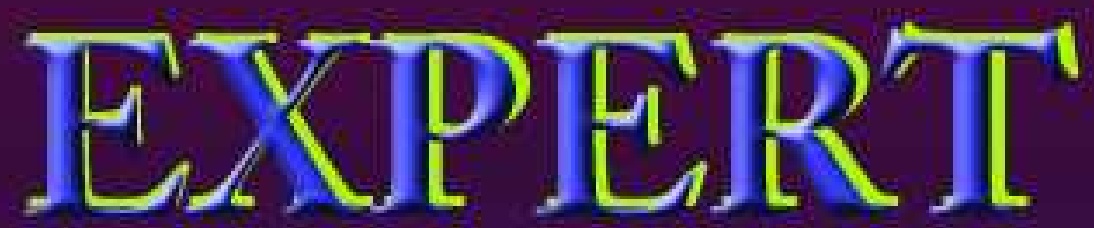

Jurnal Sistem Informasi

PERANCANGAN PROTOTYPE TEKNOLOGI SMART BUILDING MENGGUNAKAN ARDUINO BERBASIS WEB SERVER UNTUK MENDUKUNG PEMBANGUNAN PROPINSI LAMPUNG MENUJU PROGRAM LAMPUNG "SMART CITY"

Budi Usmanto, Tri Susilowati

SISTEM PENDUKUNG KEPUTUSAN PERANGKINGAN SEKOLAH MENENGAH KEJURUAN (SMK) DI KABUPATEN PRINGSEWU MENGGUNAKAN METODE WEIGHTED PRODUCT (WP)

Oktafianto, Elisabet Yunacti Anggracni, Suyono

OTORISASI PENGGUNA LABORATORIUM IBI DARMAJAYA BERBASIS CLIENT SERVER

Hendra Kurniawan, Hermanto

SISTEM PENDUKUNG KEPUTUSAN BERBASIS ANALYTICAL HIERARKHI PROCESS UNTUK PENENTUAN PENGISIAN JABATAN

Fenty Ariani

SEBARAN MENARA TELEKOMUNIKASI SELULER BERSAMA BERBASIS GIS (GEOGRAPHIC INFORMATION SYSTEM)

DI WILAYAH KABUPATEN LAMPUNG TENGAH

Taqwan Thamrin, Wiwin Susanty

AUTHENTIFIKASI LOGIN USER PADA PERANGKAT LUNAK MENGGUNAKAN ARDUINO DAN ENKRIPSI AES 256

Apri Triansah

ISSN : 2088-5555

$$
\text { Write To Be Experte }
$$




\section{Expert}

Jurnal Manajemen Sistem Informasi dan Teknologi

Volume 07, Nomor 02, Desember 2017

\begin{tabular}{|c|c|}
\hline Judul & Hal \\
\hline $\begin{array}{lllr}\text { PERANCANGAN } & \text { PROTOTYPE } & \text { TEKNOLOGI } & \text { SMART } \\
\text { BUILDING } & \text { MENGGUNAKAN ARDUINO BERBASIS WEB } \\
\text { SERVER } & \text { UNTUK } & \text { MENDUKUNG PEMBANGUNAN } \\
\text { PROPINSI LAMPUNG } & \text { MENUJU PROGRAM LAMPUNG } \\
\text { "SMART CITY" } & & & \\
\end{array}$ & $57-65$ \\
\hline $\begin{array}{l}\text { SISTEM PENDUKUNG KEPUTUSAN PERANGKINGAN } \\
\text { SEKOLAH MENENGAH KEJURUAN (SMK) DI KABUPATEN } \\
\text { PRINGSEWU MENGGUNAKAN METODE WEIGHTED } \\
\text { PRODUCT (WP) }\end{array}$ & $66-71$ \\
\hline $\begin{array}{l}\text { OTORISASI } \quad \text { PENGGUNA } \quad \text { LABORATORIUM } \\
\text { DARMAJAYA BERBASIS CLIENT SERVER }\end{array}$ & $72-76$ \\
\hline $\begin{array}{l}\text { SISTEM PENDUKUNG KEPUTUSAN BERBASIS } \\
\text { ANALYTICAL HIERARKHI PROCESS UNTUK PENENTUAN } \\
\text { PENGISIAN JABATAN }\end{array}$ & $77-82$ \\
\hline $\begin{array}{l}\text { SEBARAN MENARA TELEKOMUNIKASI SELULER } \\
\text { BERSAMA BERBASIS GIS (GEOGRAPHIC INFORMATION } \\
\text { SYSTEM) DI WILAYAH KABUPATEN LAMPUNG TENGAH }\end{array}$ & $83-89$ \\
\hline $\begin{array}{l}\text { AUTHENTIFIKASI LOGIN USER PADA PERANGKAT } \\
\text { LUNAK MENGGUNAKAN ARDUINO DAN ENKRIPSI AES } \\
256\end{array}$ & $90-95$ \\
\hline
\end{tabular}

Fakultas Ilmu Komputer

Universitas Bandar Lampung

\begin{tabular}{|c|c|c|c|c|}
\hline \multirow{2}{*}{ JMSIT } & Volume 07 & Nomor 02 & Lampung, Desember & ISSN \\
& & 2017 & $2088-5555$ \\
\hline
\end{tabular}




\section{TIM PENYUNTING}

\section{Penanggung Jawab}

Ahmad Cucus, S.Kom., M.Kom.

Ketua Tim Redaksi:

Taqwan Thamrin, ST, M.Sc.

Penyunting Ahli (Mitra Bestari):

Mustofa Usman, Ph.D (Universitas Lampung)

Dra. Wamiliana, MA., Ph.D (Universitas Lampung)

Iing Lukman, M.Sc., Ph. D (Universitas Malahayati)

\section{Penyunting:}

Fenty Ariani, S.Kom, M.Kom

Robby Yuli Endra, S.Kom.,M.Kom

Ayu Kartika Puspa, S.Kom, M.TI

Erlangga, S.Kom, M.Kom

\section{Pelaksana Teknis:}

Dian Resha Agustina, S.Kom

\section{Alamat Penerbit/Redaksi:}

Pusat Studi Teknologi Informasi

Fakultas Ilmu Komputer

Universitas Bandar Lampung

Gedung Business Center Lt.2

Jl. Zainal Abidin Pagar Alam No. 26

Bandar Lampung

Email: Journal.expert@ubl.ac.id 


\title{
SISTEM PENDUKUNG KEPUTUSAN PERANGKINGAN SEKOLAH MENENGAH KEJURUAN (SMK) DI KABUPATEN PRINGSEWU MENGGUNAKAN METODE WEIGHTED PRODUCT (WP)
}

\author{
Oktafianto $^{\# 1}$, Elisabet Yunaeti Anggraeni ${ }^{* 2}$, Suyono $^{\# 3}$ \\ ${ }^{\# 1 * 2}$ Program Studi Manajemen Informatika \\ Program Studi Sistem Informasi ${ }^{\# 3}$ \\ STMIK Pringsewu Lampung \\ Jl. Wisma Rini No. 09 Pringsewu Lampung \\ ${ }^{1}$ oktafianto@stmikpringsewu.ac.id \\ ${ }^{2}$ elisabet.sugiantodyahoo.co.id \\ ${ }^{3}$ yono.psw@gmail. com
}

\begin{abstract}
ABSTRAK
Penelitian ini menganalisis sistem pendukung keputusan dalam perangkingan Sekolah Menengah Kejuruan (SMK) di Kabupaten Pringsewu. Kesulitan yang dihadapi oleh stakeholder baik itu pemerintah maupun masyarakat umum di Kabupaten Pringsewu adalah belum mengetahui tingkat kualitas Sekolah Menengah Kejuruan (SMK) di Kabupaten Pringsewu, karena hal ini sangat berkaitan dengan kebijakan yang akan diambil oleh pemerintah ketika ada penyaluran hibah langsung. Sedangkan bagi masyarakat, yaitu terkait Sekolah Menengah Kejuruan (SMK) mana yang akan dipilih untuk menyekolahkan anaknya. Penelitian ini menggunakan enam criteria dalam perangkingan Sekolah Menengah Kejurun (SMK). Keenam criteria tersebut adalah gedung/ruang belajar, perpustakaan, ketersediaan laboratorium, akreditasi sekolah, linearitas keilmuan pendidik dan persentase siswa yang lulus dalam ujian nasional. Setelah dilakukan perhitungan menggunakan metode Weighted Product (WP), maka diperoleh Sekolah Menengah Kejuruan (SMK) yang unggul di Kabupaten Pringsewu.
\end{abstract}

Kata Kunci: SPK, SMK, Weighted Product

\section{PENDAHULUAN \\ 1.1 Latar Belakang}

Perkembangan dunia pendidikan saat ini sedang memasuki era yang ditandai dengan gencarnya inovasi teknologi, sehingga menuntut adanya penyesuaian sistem pendidikan yang selaras dengan tuntutan dunia kerja. Pendidikan harus mencerminkan proses memanusiakan manusia dalam arti mengaktualisasikan semua potensi yang dimilikinya menjadi kemampuan yang dapat dimanfaatkan dalam kehidupan sehari - hari di masyarakat luas. Salah satu lembaga pada jalur pendidikan formal yang menyiapkan lulusannya untuk memiliki keunggulan di dunia kerja, diantaranya melalui jalur pendidikan kejuruan.

Sekolah Menengah Kejuruan (SMK) dirancang untuk menyiapkan peserta didik atau lulusan yang siap memasuki dunia kerja dan mampu mengembangkan sikap profesional di bidangnya. Namun Sekolah Menengah Kejuruan (SMK) dituntut bukan hanya sebagai penyedia tenaga kerja yang siap bekerja pada lapangan kerja yang sesuai dengan kebutuhan dunia usaha / dunia industri, tetapi juga dituntut untuk mengembangkan diri pada jalur wirausaha, agar dapat maju dalam berwirausaha walaupun dalam kondisi dan situasi apapun. (Aji Pamurti, 2008)

Semakin banyaknya minat dan keinginan masyarakat Pringsewu untuk melanjutkan pendidikan ke Sekolah Menengah Kejuruan, membuat Sekolah Menengah Kejuruan (SMK) di Kabupaten Pringsewu termotivasi untuk senantiasa berusaha meningkatkan kualitas dan mutu sekolah. Kesulitan yang dihadapi oleh stakeholder baik itu pemerintah maupun masyarakat umum di Kabupaten Pringsewu adalah belum mengetahui tingkat kualitas Sekolah Menengah Kejuruan di Kabupaten Pringsewu, karena hal ini sangat berkaitan dengan kebijakan yang akan di ambil oleh pemerintah ketika ada penyaluran hibah langsung. Sedangkan bagi masyarakat, yaitu terkait dengan Sekolah Menengah Kejuruan mana yang akan dipilih untuk menyekolahkan putra-putrinya. (Anggraeni, 2017)

Berkaitan dengan hal tersebut maka penulis tertarik untuk melakukan penelitian terkait dengan perangkingan Sekolah Menengah Kejuruan (SMK) di Kabupaten Pringsewu menggunakan Metode Weighted Product (WP). 


\subsection{Permasalahan Penelitian}

\subsubsection{Identifikasi Masalah}

Berdasarkan latar belakang di atas, maka ditemukan beberapa masalah yaitu:

a. Kriteria-kriteria apa saja yang digunakan dalam perangkingan Sekolah Menengah Kejuruan (SMK) di Kabupaten Pringsewu?

b. Bagaimana penerapan metode Weighted Product (WP) ke dalam sistem pendukung keputusan perangkingan Sekolah Menengah Kejuruan (SMK) di Kabupaten Pringsewu?

\subsection{Rumusan dan Batasan Masalah}

\subsubsection{Rumusan Masalah}

Berdasarkan uraian di atas, maka rumusan permasalahan yang akan dikaji dalam penelitian ini adalah: "Bagaimanakah proses perangkingan Sekolah Menengah Kejuruan (SMK) di Kabupaten Pringsewu?

\subsubsection{Batasan Masalah}

Batasan masalah dalam penelitian ini adalah:

1. Penelitian ini hanya merangkingkan Sekolah Menengah Kejuruan (SMK) yang ada di Kabupaten Pringsewu.

2. Penelitian ini menggunakan Metode Weighted Product (WP) dalam merangkingkan Sekolah Menengah Kejuruan (SMK) yang ada di Kabupaten Pringsewu.

\section{TINJAUAN PUSTAKA DAN LANDASA TEORI}

\subsection{Tinjauan Pustaka}

Tinjuan pustaka diambil dari beberapa buku, jurnal dan artikel yang berhubungan dengan penelitian ini adalah sebagai berikut:

a. Penelitian yang dilakukan oleh Elisabet Yunaeti Anggraeni \& Oktafianto, dengan judul: Penerapan Metode Fuzzy Simple Additive Waighting (FSAW) Dalam Penentuan Perankingan Sekolah Menengah Kejuruan (SMK) Di Kabupaten Pringsewu. Dimuat dalam prosiding Semnasteknomedia, 5(1), 3-5.

b. Penelitian yang dilakukan oleh Ahmadi, A., \& Wiyanti, D. T. (2014, June), dengan judul Implementasi Weighted Product (WP) dalam Penentuan Penerima Bantuan Langsung Masyarakat PNPM Mandiri Perdesaan. In Seminar Nasional Aplikasi Teknologi Informasi (SNATI) (Vol. 1, No. 1)

\subsection{Sistem Pendukung Keputusan}

Menurut Mat dan Watson dalam Kusumadewi (2007), Sistem Penunjang Keputusan (SPK) merupakan suatu system interaktif yang membantu pengambilan keputusan melalui penggunaan data dan model-model keputusan untuk memecahkan masalah-masalah yang sifatnya semi terstruktur dan tidak terstruktur.

Sedangkan menurut Moore dan Chang (1995: 84) dalam Kusumadewi (2007), SPK adalah sistem yang dapat dikembangkan, mampu mendukung analisis data dan pemodelan keputusan, berorientasi pada perencanaan masa mendatang, serta tidak bisa direncanakan interval (periode) waktu pemakaiannya.

Bonezek, Hosapple dan Whinston (1995: 84) dalam Kusumadewi (2007) mendefinisikan SPK sebagai suatu sistem yang berbasiskan komputer yang terdiri dari 3 komponen yang berinteraksi satu dengan yang lainnya.

1. Language system, adalah suatu mekanisme untuk menjembatani (interface) pemakai dan komponen lainnya.

2. Knowledge system, adalah repositori pengetahuan yang berhubungan dengan masalah tertentu baik berupa data maupun prosedur.

3. Problem processing system, adalah sebagai penghubung kedua komponen lainnya, berisi satu atau beberapa kemampuan manipulasi atau menyediakan masalah secara umum, yang diperlukan dalam pengambilan keputusan.

\subsection{Metode Weighted Product (WP)}

Metode Weighted Product (Basyaib, 2006: 139) merupakan metode pengambilan keputusan dengan cara perkalian untuk menghubungkan rating atribut, dimana rating setiap atribut harus dipangkatkan dulu dengan bobot atribut yang bersangkutan.

Savitha, K., Chandrasekar, C., (2011) dalam Andri Syafrianto menyebutkan secara umum, prosedur Metode Weighted Product mengikuti langkah-langkah sebagai berikut:

1. Menentukan kriteria yang akan digunakan sebagai parameter penilaian.

2. Melakukan perhitungan nilai relatif bobot awal (wj). Nilai bobot awal (w0) digunakan untuk menunjukkan tingkat kepentingan relatif dari setiap kriteria. Nilai bobot awal (w0) dinormalisasi menggunakan rumus 1 sehingga total nilai relatif bobot awal $\Sigma$ wj $=1$. 


$$
W_{j}=\frac{w_{j}}{\sum w_{j}}
$$

3. Melakukan perhitungan nilai preferensi untuk setiap alternatif Ai (vektor S). Perhitungan nilai preferensi untuk alternatif $\mathrm{Ai}$ diawali dengan memberikan nilai rating kinerja ke-i terhadap kriteria ke j (xij). Setelah masing-masing kandidat nilai rating kinerja, nilai ini akan dipangkatkan dengan nilai relatif bobot yang telah dihitung sebelumnya $(\mathrm{Wj})$. $\mathrm{Wj}$ akan bernilai positif untuk atribut benefit (keuntungan) dan bernilai negatif untuk atribut cost (biaya). Rumus yang digunakan untuk menghitung nilai preferensi untuk setiap alternatif $\mathrm{Ai}$ (vektor $\mathrm{S}$ ) adalah rumus:

$$
S_{i}=\prod_{j=i}^{n} X_{i j}^{W_{j}}
$$

Dengan $\mathrm{i}=1,2,3 \ldots \mathrm{m}$

4. Melakukan perhitungan nilai preferensi relatif dari setiap alternatif menggunakan rumus:

$$
V_{i}=\frac{\prod_{j=i}^{n} X_{i j}^{W_{j}}}{\prod_{j=i}^{n}\left(X_{j}^{*}\right)^{W_{j}}}
$$

Dengan $\mathrm{i}=1,2,3, \ldots \mathrm{m}$

Perhitungan nilai preferensi untuk alternatif $\mathrm{Ai}$ dilakukan dengan membagi nilai vektor $\mathrm{S}$ pada perumahan ke-i dan kriteria ke-j.

\section{METODE PENELITIAN}

\subsection{Metode Penelitian}

Metode penelitian pada dasarnya merupakan cara ilmiah untuk mendapatkan data dengan tujuan dan kegunaan tertentu (Sugiono, 2013: 2). Dalam penelitian ini penulis menggunakan metode penelitian kuantitatif, metode penelitian kuantitatif yaitu penelitian yang membuat gambaran mengenai permasalahan yang telah diidentifikasi oleh penulis, dimana objek yang diteliti dijelaskan dari sudut pandang penulis (Sugiono, 2013).

\subsection{Metode Pengumpulan Data}

a. Metode Observasi

Observasi merupakan metode pengumpulan data dengan cara melakukan pengamatan secara langsung terhadap objek yang diteliti yaitu dengan melihat langsung SMK di Kabupaten Pringsewu.

b. Metode Wawancara

Metode wawancara merupakan metode pengumpulan data informasi dengan cara melakukan wawancara dengan pihak SMK di Kabupaten Pringsewu dan Kepala Dinas Pendidikan Kabupaten Pringsewu.

c. Studi Pustaka

Merupakan tahapan yang dilakukan dengan membaca buku metode Weighted Product (WP), penilaian sekolah terbaik, serta buku lain yang menunjang penelitian ini.

\section{HASIL DAN PEMBAHASAN}

\subsection{Perhitungan Metode Weighted Product (WP)}

Berikut ini merupakan kriteria yang dibutuhkan untuk pengambilan keputusan:

$$
\begin{aligned}
& \text { C1 }=\text { Jumlah siswa per kelas } \\
& \text { C2 }=\text { Perpustakaan } \\
& \text { C3 }=\text { Ketersediaan laboratorium } \\
& \text { C4 }=\text { Akreditasi sekolah } \\
& \text { C5 }=\text { Linearitas keilmuan pendidik } \\
& \text { C6 }=\text { Persentase siswa lulus ujian nasional }
\end{aligned}
$$

Tiga SMK yang akan dinilai memiliki data sebagai berikut:

Tabel 1. Simulasi Perhitungan SMK Unggulan

\begin{tabular}{|l|c|c|c|}
\hline \multirow{2}{*}{\multicolumn{1}{|c|}{ Kriteria }} & \multicolumn{3}{|c|}{$\begin{array}{c}\text { Sekolah Menengah Kejuruan } \\
\text { (SMK) }\end{array}$} \\
\cline { 2 - 4 } & $\begin{array}{c}\text { SMK 1 } \\
\text { (A1) }\end{array}$ & $\begin{array}{c}\text { SMK 2 } \\
\text { (A2) }\end{array}$ & $\begin{array}{c}\text { SMK 3 } \\
\text { (A3) }\end{array}$ \\
\hline $\begin{array}{l}\text { Jumlah siswa per kelas } \\
\text { (C1) }\end{array}$ & 35 & 30 & 40 \\
\hline Perpustakaan (C2) & 240 & 256 & 300 \\
\hline $\begin{array}{l}\text { Ketersediaan } \\
\text { laboratorium (C3) }\end{array}$ & 1 & 1 & 1 \\
\hline Akreditasi sekolah (C4) & 325 & 315 & 305 \\
\hline $\begin{array}{l}\text { Linearitas keilmuan } \\
\text { pendidik (C5) }\end{array}$ & $100 \%$ & $90 \%$ & $95 \%$ \\
\hline $\begin{array}{l}\text { Persentase siswa lulus } \\
\text { ujian nasional (C6) }\end{array}$ & 100 & 100 & 100 \\
\hline
\end{tabular}

Berdasarkan data di atas dapat dibentuk matriks keputusan $\mathrm{X}$ yang telah di konversikan dengan bilangan fuzzy, sebagai berikut: 
Tabel 2. Konversi matriks keputusan $X$

\begin{tabular}{|c|c|c|c|c|c|c|}
\hline \multirow{2}{*}{ Alternative } & \multicolumn{6}{|c|}{ Kriteria } \\
\cline { 2 - 7 } & C1 & C2 & C3 & C4 & C5 & C6 \\
\hline A1 & 35 & 240 & 1 & 325 & 100 & 100 \\
\hline A2 & 30 & 256 & 1 & 315 & 90 & 100 \\
\hline A3 & 40 & 300 & 1 & 305 & 95 & 100 \\
\hline
\end{tabular}

Tingkat kepentingan setiap criteria juga dinilai dengan 1 sampai 5, yaitu:

$1=$ sangat rendah

$2=$ rendah

$3=$ cukup

$4=$ tinggi

$5=$ sangat tinggi

Pengambilan keputusan memberikan bobot, berdasarkan tingkat kepentingan masing-masing kriteria yang dibutuhkan sebagai berikut:

Vector Bobot: $\mathrm{W}=[5,3,4,3,4,3]$

Kategori setiap criteria:

Criteria $\mathrm{C} 1$ (jumlah siswa per kelas) adalah criteria biaya. Sedangkan $\mathrm{C} 2=$ Perpustakaan, $\mathrm{C} 3=$ Ketersediaan laboratorium, $\mathrm{C} 4=$ Akreditasi sekolah, C5 = Linearitas keilmuan pendidik, C6 = Persentase siswa lulus ujian nasional adalah criteria keuntungan.

Sebelumnya dilakukan perbaikan bobot terlebih dahulu, sehingga total bobot $\Sigma \mathrm{W}_{\mathrm{j}}=1$ dengan cara :

$$
W_{j}=\frac{w_{j}}{\sum w_{j}}
$$

Dari bobot preferensi sebelumnya yaitu $\mathrm{W}=(5,3$, $4,3,4,3) . \mathrm{W}_{\mathrm{j}}$ merupakan $\mathrm{W}$ index ke $\mathrm{j}$. Jadi untuk $\mathrm{W}_{1}$ yaitu $5, \mathrm{~W}_{2}$ yaitu 3 dan seterusnya. Dan $\Sigma \mathrm{W}_{\mathrm{j}}$ merupakan jumlah dari $\mathrm{W}$ yaitu $5+3+4+4+2$

Jadi untuk perbaikan bobot $\mathrm{W}_{1}$ menjadi:

$$
\begin{aligned}
& W_{1}=\frac{5}{5+3+4+3+4+3}=\frac{5}{22}=0.23 \\
& W_{2}=\frac{3}{5+3+4+3+4+3}=\frac{3}{22}=0.14 \\
& W_{1}=\frac{4}{5+3+4+3+4+3}=\frac{4}{22}=0.18 \\
& W_{4}=\frac{3}{5+3+4+3+4+3}=\frac{3}{22}=0.14
\end{aligned}
$$

$$
W_{5}=\frac{4}{5+3+4+3+4+3}=\frac{4}{22}=0.18
$$

$$
W_{6}=\frac{3}{5+3+4+3+4+3}=\frac{3}{22}=0.14
$$

Tahap selanjutnya adalah menentukan Nilai Vektor $S$, yang dapat dihitung dengan menggunakan formula berikut:

$$
S_{i}=\prod_{j=i}^{n} X_{i j}^{W_{j}}
$$

Untuk perhitungan sederhananya, kembali lihat Tabel 2 di atas. Pada baris R1, masing-masing kriteria memiliki nilai sebagai berikut:
$\mathrm{C} 1=35$
$\mathrm{C} 2=240$
$\mathrm{C} 3=1$
$\mathrm{C} 4=325$
C5 $=100$
$\mathrm{C} 6=100$

Pangkatkan dan kalikan nilai masing-masing kriteria tersebut dengan bobot yang sudah diperbaiki sebelunya. Jadi seperti berikut:

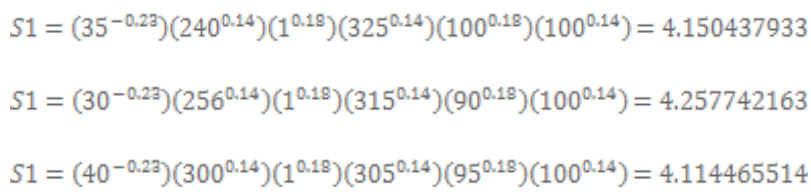

Tahap selanjutnya adalah menentukan nilai vector yang akan digunakan Menghitung Preferensi (Vi) untuk perangkingan. Formulanya seperti berikut:

$$
\mathrm{V}_{\mathrm{i}}=\frac{\prod_{J=1}^{n} X_{i j} \mathrm{wj}}{\prod_{J=1}^{n}\left(X_{j} * \mathrm{wj}\right.}
$$

Sederhananya seperti:

$$
\mathrm{V}_{1}=\frac{\mathrm{S}_{1}}{\mathrm{~S}_{1}+\mathrm{S}_{2}+\mathrm{S}_{3}}
$$

Jadi Hasil dari menghitung preferensi (Vi) adalah sebagai berikut:

$$
\begin{aligned}
& V 1=\frac{4.150437933}{4.150437933+5.257742163+4.114465514}=0.331435 \\
& V 2=\frac{5.257742163}{4.150437933+5.257742163+4.114465514}=0.430003 \\
& V 3=\frac{4.114465514}{4.150437933+5.257742163+4.114465514}=0.328562
\end{aligned}
$$


Dari hasil perhitungan di atas, nilai $\mathrm{V}_{2}$ menunjukkkan nilai terbesar sehingga dengan kata lain $\mathrm{V}_{2}$ merupakan pilihan alternatif yang terbaik, SMK 2 menjadi SMK unggulan sesuai dengan pembobotan yang diberikan oleh pengambil keputusan.

\section{KESIMPULAN}

Berdasarkan hasil penelitian dan pembahasan yang dilakukan maka kesimpulan dari penelitian ini adalah sistem pendukung keputusan dapat memberikan pengetahuan bagaimana cara menentukan SMK unggulan pada Kabupaten Pringsewu.

\section{DAFTAR PUSTAKA}

[1] Ahmadi, A., \& Wiyanti, D. T. (2014, June). Implementasi Weighted Product (WP) dalam Penentuan Penerima Bantuan Langsung Masyarakat PNPM Mandiri Perdesaan. In Seminar Nasional Aplikasi Teknologi Informasi (SNATI) (Vol. 1, No. 1).
[2] Aji Pamurti, Andarina (2008) Sekolah Menengah Kejuruan Pariwisata Bertaraf International Di Semarang. Undergraduate Thesis, Jurusan Arsitektur Fakultas Teknik Undip.

[3] Andri Syafrianto, Perancangan Sistem Pendukung Keputusan Untuk Pemilihan Lokasi Perumahan Menggunakan Weighted Product Model (WPM), STMIK El Rahma

[4] Anggraeni, E. Y., \& Oktafianto, O. (2017). Penerapan Metode Fuzzy Simple Additive Waighting (FSAW) Dalam Penentuan Perankingan Sekolah Menengah Kejuruan (SMK) Di Kabupaten Pringsewu. Semnasteknomedia Online, 5(1), 3-5.

[5] Basyaib Fachmi (2006). Teori Pembuatan Keputusan, Jakarta : PT. Grasindo

[6] Kusumadewi, Sri., Hartati, S., Harjoko, A., dan Wardoyo, R. (2007). Fuzzy Multi-Attribute Decision Making (FUZZY MADM). Yogyakarta: Penerbit Graha Ilmu.

[7] Sugiono. (2013). Metode Penelitian Kuantitatif, Kualitatif dan R \& D. Bandung: Alfabeta. 


\title{
Template Penulisan Jurnal Expert
}

\author{
First Author ${ }^{\# 1}$, Second Author ${ }^{* 2}$, Third Author ${ }^{\# 3}$ \\ ${ }^{\#}$ First-Third Department, First-Third University \\ Address Including Country Name \\ ${ }^{1}$ first.authorefirst-third.edu \\ ${ }^{3}$ third.authorefirst-third.edu \\ *Second Company \\ Address Including Country Name \\ ${ }^{2}$ second. authoresecond. com
}

\section{Abstrak}

Abstrak dalam bahasa Indonesia ditulis dengan rata kiri-kanan, dengan satu spasi dan satu kolom. Kata "Abstrak" sebagai judul ditulis dalam huruf Times 11-point, tebal, rata tengah, dengan huruf pertama dikapitalkan. Teks abstrak ditulis dengan huruf Times 10-point, satu spasi, sampai lebih kurang 150 kata. Sesudah abstrak tuliskan kata kunci dari makalah tersebut dalam daftar kata kunci. Kemudian dilanjutkan dengan teks utama makalah.

Kata kunci : : kata kunci abstrak

\section{Pendahuluan}

Semua makalah ditulis dalam bahasa Indonesia. Panduan penlisian ini dilengkapi dengan deskripsi huruf, spasi, dan informasi lainnya yang berhubungan dengan penulisan makalah anda. Diharapkan semua penulis dapat mengikuti template yang disediakan dan jika terdapat pertanyaan, silahkan menghubungi editor jurnal EXPERT di journal.expert@ubl.ac.id atau telefon +62721774626 .

\section{Format penulisan}

Materi yang akan dicetak, meliputi teks, gambar ilustrasi, dan grafik harus berada dalam area pencetakan yaitu bidang kertas A4 dengan margin 2.5 $\mathrm{cm}$ di semua sisi kertas. Jangan menuliskan atau meletakkan sesuatu diluar bidang cetak tersebut Seluruh teks ditulis dalam format dua kolom dengan lebar kolom $7.5 \mathrm{~cm}$ dan jarak antar kolom $1 \mathrm{~cm}$, kecuali bagian abstrak yang dituliskan dalam format satu kolom. Seluruh teks harus rata kiri-kanan.

Template ini menggunakan format yang dianjurkan. Untuk mempermudah penulis dalam memformat makalah/jurnalnya, format ini dapat digunakan sebagai petunjuk atau format dasar penulisan.

\section{Judul utama}

Judul utama (pada halaman pertama) harus dituliskan dengan jarak margin $2 \mathrm{~cm}$ dari tepi kertas, rata tengah dan dalam huruf Times 14-point, tebal, dengan huruf kapital pada huruf pertama dari kata benda, kata ganti benda, kata kerja, kata sifat, dan kata keterangan; jangan menggunakan huruf kapital pada kata sandang, kata hubung, terkecuali jika judul dimulai dengan kata-kata tersebut. Sisakan satu 11point baris kosong sesudah judul.

\section{Nama penulis dan afiliasi}

Nama penulis dan afiliasi diletakkan ditengah dibawah judul dan dituliskan dengan huruf Times 11point, tidak tebal. Afiliasi dan email penulis dituliskan dibawahnya dengan huruf Times 10-point, miring. Penulis yang lebih dari satu orang dituliskan dalam dua atau tiga kolom, dengan afiliasi dan email masingmasing.

\section{Tipe huruf}

Huruf yang digunakan adalah turunan dari huruf Times, meliputi Times Roman atau Times New Roman. Jika tipe huruf tersebut didak tersedia pada aplikasi pengolah kata yang digunakan, usahakan untuk memilih huruf yang memiliki kemiripan sedekat mungkin dengan Times. Hindari penggunaan huruf bit-mapped. Diharapkan untuk menggunakan huruf-huruf True-type 1.

\section{Teks utama}

Ketik teks utama dengan menggunakan huruf Times 10-point, satu spasi. Jangan menggunakan dua spasi. Setiap paragraf sebaiknya memiliki panjang lebih kurang $0.5 \mathrm{~cm}$. Pastikan teks ditulis dengan rata kiri-kanan. Jangan menambahkan baris kosong di antara paragraf. Istilah dalam bahasa asing (foreign language) yang tidak dapat diterjemahkan dalam bahasa utama makalah harus dituliskan dalam huruf miring.

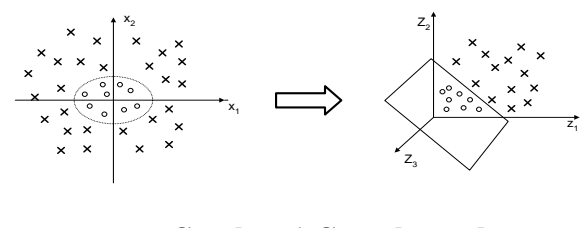

\section{Gambar 1 Contoh gambar}

Keterangan gambar dan tabel dituliskan dengan huruf Times 9-point. Sedangkan pengacuan gambar pada teks menggunakan huruf Times 10-pont. Keterangan gambar diletakkan di bawah, tengah gambar yang dijelaskan. Keterangan tabel diletakkan sebelum tabel dengan rata kiri.

Uraian yang dalam bentuk list (bulleted) dituliskan untuk:

- Uraian yang tidak memiliki aturan pengurutan tertentu

- Uraian yang tidak terikat antara uraian yang satu dan lainnya 


\begin{tabular}{|l|l|l|}
\hline No. & Jumlah & Kecepatan \\
\hline 1. & 25 & $10 \mathrm{~s}$ \\
\hline 2. & 50 & $15 \mathrm{~s}$ \\
\hline
\end{tabular}

Sedangkan untuk uraian yang berurutan dituliskan dengan penanda huruf, untuk:

a. Uraian yang memiliki aturan pengurutan

b. Uraian yang terkait dengan uraian lainnya

c. Uraian yang setiap itemnya akan diacu pada tulisan utama

\section{Judul pertama}

Sebagai contoh, "1. Pendahuluan", dituliskan dalam huruf Times 11-point, tebal, huruf pertama kata pertama ditulis dengan huruf kapital. Gunakan tanda titik (".") sesudah nomor judul.

\subsection{Judul kedua}

Sebagaimana judul pertama, judul kedua dituliskan dengan huruf Times 11-point, tebal. Nomor judul terdiri dari dua angka yang dibatasi dengan tanda titik. Tidak ada titik sesudah nomor judul dengan teks judul.

\subsubsection{Judul ketiga}

Untuk uraian yang lebih panjang dan tidak dapat dituliskan dalam bentuk uraian terurut, digunakan judul ketiga. Judul ketiga menggunakan ukuran huruf yang lebih kecil dari judul pertama dan judul kedua yaitu huruf Times 10-point, tebal. Nomor judul terdiri dari tiga angka yang dibatasi dengan tanda titik. Tidak ada titik sesudah nomor judul dengan teks judul.

\section{Catatan kaki}

Penggunaan catatan kaki dimaksudkan untuk membatu pembaca memperoleh penjelasan terhadap kalimat dalam teks tulisan utama. Catatan kaki dituliskan pada bagian bawah kolom yang memuat acuan ke catatan kaki tersebut. Catatan kaki ditulis dengan huruf Times 8-point, satu spasi. Hindari penggunaan banyak catatan kaki.

\section{Pemrograman}

Listing program dan disain algoritma dituliskan dengan menggunakan huruf dengan lebar yang tetap seperti Courier New 9-point.

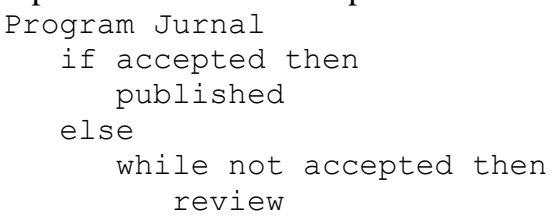

Sedangkan notasi matematika dituliskan dengan menggunakan simbol notasi yang sesuai.

\section{Daftar pustaka}

Daftar pustaka memuat daftar bacaan yang diacu dalam tulisan utama. Daftar pustaka ditulis dengan metode penulisan kepustakaan APA (American Psychological Association) Style, dengan huruf Times 10 -point. Kutipan dalam teks utama yang mengacu kepada daftar pustaka dituliskan dengan angka dalam kurung siku [nama penulis, tahun].

[1] A.B. Smith, C.D. Jones, and E.F. Roberts, Article Title, "Journal", Publisher, Location, Date, Years, pp. 1-10.

[2] Jones, C.D., A.B. Smith, and E.F. Roberts, Book Title, Publisher, Location, Date.

[3] S. Zhang, C. Zhu, J. K. O. Sin, and P. K. T. Mok, "A novel ultrathin elevated channel lowtemperature poly-Si TFT," IEEE Electron Device Lett., vol. 20, pp. 569-571, Nov. 2016. 
Redaksi :

Pusat Studi Teknologi Informasi (PSTI). Gedung Business Center Lt 2 J. Zainal Abidin No. 26 Bandar Lampung Telp. 0721 - 774626 9 772088 " 555000

SistemInformasi@ubl.ac.id 